The Silence of the Gods

Author(s): Maggie Leggitt

Source: All Ireland Review, Vol. 2, No. 39 (Nov. 30, 1901), p. 310

Published by: All Ireland Review

Stable URL: http://www.jstor.org/stable/20545676

Accessed: 15-03-2016 03:24 UTC

Your use of the JSTOR archive indicates your acceptance of the Terms \& Conditions of Use, available at http://www.jstor.org/page/ info/about/policies/terms.jsp

JSTOR is a not-for-profit service that helps scholars, researchers, and students discover, use, and build upon a wide range of content in a trusted digital archive. We use information technology and tools to increase productivity and facilitate new forms of scholarship. For more information about JSTOR, please contact support@ jstor.org. 
Silence, then, for a while at least, an improper expression. If you think, North and South. We know now, all for a moment, you will see that it is so. of us, that there is a spirit of ferocious It is a very improper expression." bigotry abroad in Ireland still prevalent, a state of mind worthy of the 16 th century, of that black time when we slew and burned each other for the love of God We know, too, that this devilish spirit might, conceivably, were the strong arm of authority suddenly relaxed, amongst this backward and still very mediævallyminded people, flame forth once more, letting Hell loose in our land. Also, we know it is best to bear always in mind even the ugliest of facts, that we have, especially in our great towns and cities, multitudes of lewd fellows of the baser sort who of lewd fellows of the baser sort who
on the least provocation, will express those mediæval passions in their own vile dialect, provoking from others a corresponding ferocity of speech, and that these people have votes and political power, and must be reckoned with.

But, if you are of "the Big Church," prove it by your magnanimity which as you know, means bigness of mind. Ignore utterly the insults of the low and the ignorant; forget, too-it is the part of the magnanimous - even the savagery of those who ought to know better, and above all avoid-I always do-in all mixed company any dan gerous comparison of the tenets and doctrines of the two great camps, anything whatsoever that might stir into malignant activity those serpents of the mind which, if left alone, will sink deeper and deeper into coma till they breathe their bed last, and all the swifter if charmed into sleep by that magnanimity which you profess, and the daily use of those grand old human and even common qualities of good nature and good sense, and the feeling that we are all children of a common Father and of one country hard be-stead, indeed, and suffering, but whose one hope of escape from trouble is by the road here indicated.

You and Brian Og, both, I am pleased to note, refer to your angry passions as things of the past, and I may add that, in a private letter, Brian Og tells me that "the sword" which he introduced into his first letter was only a sword metaphorical, and meant no more than a clean and absolute separation from any thought of ever becoming friends with us at all or of making common cause with us for any purpose whatsoever.

I think myself that his rapid rhetorical pen ran away with him a little, as I think yours too has with you.

Now, dear Ulteach, a storm clears the air, and, after all,perhaps, both your angry utterances may possibly create for us an atmosphere a little more perlucent and help us to see better how those lines are to be drawn of that cumvallation which is to include all the campsand within which we or our succes sors may convert this mob of mad-parties and wolfish sects and factions into a victorious and unconquerable host.ED. A.I.R.]

\section{BITS OF IRELAND.}

TRAINING GIRLS FOR DOMESTIC SERVICE

"Now, Mary, that's the right way to set a fire ; you see it's blazing already." "Begor, it is, maam."

A pause; solemnly; "Mary, that's

"Now, say yes, quite short, by itself."
"Begor, it is, maam." inaccuracy in the following statement "I will, maam.'

"Well!"

"He'll be down immadiate, maam. I Carrickfergus, was the third de Burgh Earl of Ulster and fifth Lord of Con. Mary, you really must learn to say naught. He was son of William de yes and no."

"Sure, I will, maam."

"I will, maam."

"Yes ; but say it; say it."

"Sure, I said it, maam."

"Bring me my letters, Mary." " postman," etc., etc.

But I rather think Mary is an ary is going to Sir John de Burgh, who was son and less.

\section{THE SILENCE OF THE GODS.}

To the songs of earth we hearken, But the silences are sweet

And the night-time of the earth-world Is with melody replete.

And we hush the sound of laughter And we still the cry of pain, hat the glory of the darkness May come o'er and o'er again.

For we learn our lesson slowly, Dull of intellect are we

Till we see the wondrous beauty Shine from God's immensity.

And from out the awful silence Comes the prelude of the song, And the wings of sound are wafted

With a cadence sweet and strong.

Then the glory dies in silence, And our eyes are clear to see That the beauty of the music Is in " silent ecstasy."

$\mathrm{Oh}$, the rapture of the silence, Filling all my soul with pain Come again, oh! I beseech you Into heart and into brain.

God of all unfold Thy goodness, In the silences of sound,

And let all the earth with silenceDarkness glorified-abound.

Hush, my heart, thy master speaketh, Let thine earthly strings be dumb;

Now I feel the silence falling,

Bow thyself, lo! it has come.

$\mathrm{Oh}$ ! the glorious dark of silence,

Hearing unknown words in dreams, Conscious of their highest meaning That through all my visions teems.

MagGie LegGitt

\section{A.I.R.'s CHRISTMAS NUMBER.}

We will thank our readers to send us stories for our Christmas Number,stories which will make each particular hair, etc., etc., suitable for Christmas Evewith the lamps lowered! and the truer the better, and no matter how short.

The number will consist of 16 pages, and the price to the general public will be 2d. Postal subscribers need not send this odd penny. A. I. R. regards it as conscience-money allowed them on
account of his holidays last August.
William de Burgh known in Irish

Brown Earl of Ulster."

Now although the William de Burgh murdered at Carrickfergus was un doubtedly the third de Burgh, Earl of Ulster, yet he was not the son of the The Brown Earl was the only son of the Red Earl of Ulster. This Sir John de Burgh died vita patris in 1313, leaving an only son William de Burgh, born on 13th September, 1312, who in father the Red Earl, became the third de Burgh, Earl of Ulster, and was styled the Brown Earl. This William de Burgh, the Brown Earl, was therefore but fourteen years of age when he succeeded to the Earldom in 1326. In May, 1327, he obtained a dispensation from Pope John XXII. " to intermarry with a noble lady of England related to him in the fourth degree: such marriage tending to consolidate the peace between, the English and the Irish." The noble lady thus referred to was Maud, daughter of Henry Plantaganet, Duke of Lancaster. In 1328, William de Burgh, the Brown Earl of Ulster, came to Ireland from Eng. lind, and in 1330, being then but eighteen years of age, he assisted Turlough O'Conor against MacWilliam. In 1332 the Brown Earl of Ulster took prisoner his kinsman Walter, son of Sir William de Burgh, and had him starved to death in the new castle (Greencastle) in the territory of Innishowen. This Walter de Burgh's sister, Gylle Burke, was married to Richard de Maunderville, and she to revenge the death of her brother, incited her husband to kill the Brown Earl of Ulster; which Maunde ville, unhappily for himself and his posterity, accordingly did the very next year-1333 - in the neighbourhood of Carrickfergus. The Brown Earl of Ulster when murdered at Carrickfergus in 1333 had not then completed his 21st year. The "Register" of the Dominican Abbey at Athenry contains

"Obitus Domini Comitis de Ultonia qui nominabatur 'y erla Dond' qui fuit interfectus per Dominum Ricardum Monvil et per Dominum Johannen de Logan, 1333."-Yours faithfully.

DeAR M. J. B.-Mr. Burke to whom I showed your letter bids me thank you for the correction and to say that e has nothing to add.

I feel sure that you could. if you would, tell us something illuminative as to the social and political condition of Ireland in the two obscure centuries that succeeded the Norman Conquest and preceded the break-up of the Norman system towards the latter end of the reign of Edward II.

I suspect that they were centuries of 1326 , upon the death of his grandthe following entry :- 